\title{
ANALYSIS ON LISTENING EXERCISES IN LOOK AHEAD 2 (ENGLISH COURSE BOOK FOR SENIOR HIGH SCHOOL STUDENTS YEAR XI)
}

\author{
Muhammad Iqbal \\ Program Studi Pendidikan Bahasa Inggris Fakultas Keguruan dan Ilmu Pendidikan \\ Universitas JabalGhafur
}

\begin{abstract}
The title of this research is "Analysis on Listening Exercises in Look Ahead 2 (English Course Book for Senior High School Students Year XI)". The problem of this research can be stated as follow: Are the listening exercises relevance to KTSP curriculum? How the listening exercises in the text book look ahead 2 present items questions?. Its purpose was to find out whether the listening exercise in Look Ahead 2 an English Course for Senior High School Year XI published by Erlangga is relevance with the KTSP curriculum and there are twelve (12) listening exercises which is included in discrete test, 3 listening exercises which is included in communicative test and 1 listening exercises which is included in combination between both. In collecting the data, the writer used in this research is library research, which is a type of study that makes the data library as the theory to study and examine the hypotheses and concepts to obtain to get result that objective. The sample of this research was listening exercise in the text book look ahead 2. Based on the result of this research, the writer found that listening exercise based KTSP curriculum of Senior High School Grade Year XI suitable of competency standard (SK) 2, and basic competency (KD) 2.1 and 2.2. The listening exercise in Look Ahead 2, an English Course for Senior High School Grade Year XI published by Erlangga, show that the higest number of test is discrete test, so it is proper enough in improving of student's ability in listening through kind of this test.
\end{abstract}

\section{The Background of Study}

English is a language which applied as a foreign language in Indonesia. It must be taught as a compulsory subject at schools and universities level. English mastery at educational level is aimed to develop students' ability in increasing students' knowledge in various fields such as science, technology, and cultural development. To master English, students should learn and practice four skills frequently namely listening, speaking, reading, and writing.

Listening is one of the most important skills in learning English. It is a skill which considered more difficult to be mastered, because it needs more attention and concentration to comprehend the sounds (listening material). It can be said that listening is not a passive skill; the process of listening is a complex process in which many things happen simultaneously inside the mind.

Jeanne states that listening skill is the first language art skilllearned, and it develops before a child speaks. Many children develop the ability to listen carefully to the speech of others during infancy and early childhood; others do not. Because language growth has described as a receiving process followed by a sending process, a child's listening ability is important to speaking and future reading and writing success. Hearing and listening are quite different. Hearing is a process involving nerves and muscles that reach adult efficiency by age 4 to 5 . Listening is learned behavior, a mental process that is concerned with hearing, attending, discriminating, understanding, and remembering. It can be improve $\mathrm{d}$ with practice. Listening skill can be described as passive and receptive, but it involves active thinking and interpretation.

From the statements above, the writer concluded that listening skill was used since someone was a child, even more before he could speak. Listening skill involves active thinking and interpretation and it is very important part for hearing, attending, discriminating, understanding, and remembering some things. The teaching and learning English process includes four skills. Those skills should be taught and mastered by students.

The teaching and learning of those skills is not as easy as it is to say, because English has many differences form our native language. Relating to this matter, listening, as one of the language skills stated in the curriculum, is considered as the most difficult and complex skill to learn by students. Based on the writer's experiences in teaching practice from August 
16th, 2014 to December 12th, 2014 at SMA Muhammadiah, there are many students find difficulties in listening in the second language rather than in their first language. It is caused by some factors such as lack of vocabulary, listening interest, the students' background knowledge of English, language facility, social and emotional development, physical development, and other factors that may influence one's success in listening. Those factors cannot be ignored in learning listening skill in English.

From the situation above, the teacher needs to implementation of KTSP curriculum so that the teacher is not only responsible for teaching in the classroom but also able to manage the class administration. The teacher is supposed to develop the annual program, the semester program, the daily program, the remedial program, etc. Kusnandar states that the implementation of KTSP is a process of applying the idea, concept, and policy of the curriculum in the learning activity so the students can master some competencies.

As we know course book has a great role in teaching and learning process, it is like a guide for teacher in teaching and it can be a reference for student in studying. The term course book or textbook has several meaning, according to Oxford dictionary, a textbook means a book giving instruction in a branch of learning. It means that a textbook is a kind of book used in some studies at school. Meanwhile, in related to English language teaching, textbook are used in different ways in language program. For example, a reading textbook contains the main material of listening skill; some listening exercise and several questions related to it is included for measuring student's achievement in this skill.

In this research, the writer will analyze listening exercises in Look Ahead 2, an English Course for Senior High School Students grade XI Published by Erlangga. These book consist of 6 unit and 17 listening exercises. From 17 listening exercises there are seven (7) listening exercises which is included in discrete test, 5 listening exercises which is included in communicative test and 5 listening exercises which is included in combination between both. So, the writer makes research with title "Analysis on Listening Exercises in Look Ahead 2 (English Course Book for Senior High School Students Year XI)."

\section{The Problem of Study}

Based on the background of the study, the writer states the research question as follow:

1. Are the listening exercises relevance to KTSP curriculum?

2. How the listening exercises in the text book look ahead 2 present items questions?

\section{The Aims of Study}

Based on the problem above, the purposes of this research is:

1. To evaluate listening exercises in Look Ahead 2 in term of the relevance.

2. To Evaluate listening exercises in Look Ahead 2 in present iterms of questions.

\section{The Significance of Study}

This research is significan to scrutinize the books' form. It is essential in how it contribute to the field of TEFL (Teaching English as a foreign language), especially concerning the teaching materials. Thus, this thesis is hoped to help the teachers to select suitable English course book in term of listening exercise in the teaching process. For students, hopefully this research can help them in choosing a listening exercise from English course book to improve their listening skill.

\section{The Scope of Study}

The scope of the study is necessary in order to enable the writer studies more deeply. Since there are many books used in senior high schools, so the study is limited on one book, which is Look Ahead 2 (English Course Book for Senior High School Students Year XI) published by Erlangga. The study only focuses on the listening exercises in the course book in terms of its relevance with the criteria of listening exercise. The criteria are: KTSP curriculum and presence of example in materials in Look Ahead 2.

\section{The Terminology}

\section{Analysis}

Analysis is the study by examining its part. It means that analysis comes from Greek language that means "a breaking up" is the process of breaking a complex topic or substance into smaller parts to gain better understanding of it. It means that analysis on listening exercise in Look Ahead 2 (English course book for senior high school students year $\mathrm{XI})$ published by erlangga is the process of 
breaking the substance of the listening exercise in the course book.

\section{Listening Exercise}

Listening means produce something in written form so that people can read, perform or use it. Listening is the psychomotor process of receiving sound waves through the ear transmitting nerve impulses to the brain. While Nicholas defines listening as an active process in which the listener plays a very active part in constructing the overall message that is eventually exchange between listener and speaker. It means that listening is one way to communicate with other people besides speaking, reading, and listening. The word "listening" seems to be very easy to understand. However, it cannot be ignored when students write a paragraph, they should not write not only semantically correct, but also in correct grammar. While exercise is activity intended for training. Another opinion says that exercise is an activity to occupy the attention and effort of; to task and to exert for the sake of training improvement, to practice in order to develop and also to improve by practice. From the definition above, listening exercise is a task or activity to improve listening skill.

\section{Research Methods}

\section{Content Analysis}

Most of all research method needs a resource of a book (library) to combine their research. There is a little difficult to distinguish between library research and field research, both of them need a literature. The main differences are based on the purposes, functions and the position of the each research. In the field research, literature is needed as a basic theory to prepare the research design. While in the Library research, literature not only used as the preparing of research design but also it more than that, it used to get data collection of the research. The purpose of this research is to analyze the listening exercise in Look Ahead 2, an English textbook for senior high school grade XI years.

There are some steps in analyzing the data. However, in this study the writer only take four steps those are; selecting, categorizing, analyzing, and making inference.
a. Selecting
The writer reads in Look Ahead 2 and then selects which exercise could be considered as the listening exercises in every unit of the course book.

\section{b. Categorizing}

After selecting the listening exercises, it will be categorized into some aspects of writing exercise which is will be used to analyze the data. Some aspects which are will be used to analyzing data are: The listening exercises relevance or not with the KTSP curriculum and presence of example in materials.

c. Analyzing

After categorizing the listening exercises in in Look Ahead 2, the writer analyzes them by using those two aspects of evaluation that is relevance to KTSP curriculum and present of example in materials.

d. Inferencing

Based on the findings of analysis, the listening exercises in Look Ahead 2 will be inferred.

2. Procedure of Data Collection

In collecting data, the writer uses documentation study or document analysis. It was one of the types of descriptive qualitative research. It focused on analyzing documents, which were English textbooks. It sought to understand the strengths and weaknesses of English textbooks by focusing on the total listening exercises design. The aim of this descriptive qualitative research was to gain a holistic picture and depth of understanding of the strengths and weaknesses of one English textbooks. The technique in collecting data in this analysis involves several activities:

a. Reading

The first step of data collection procedure was reading the Look Ahead 2, an English Course for Senior High School Students Year XI. The writer read all text and exercises in the text book to find which exercises which are considered as the data. The data are the only the writing exercises in the textbook.

b. Identifying

After the complete reading was done, the next step was identification. I identified the number of listening exercises in every units of Look Ahead 2.

c. Listening

After identified the number of listening exercises in every unit, the writer listen to recorded listening exercises of in Look Ahead 2.

d. Classifying 
The next step was classification. The data that had been identified was then classified based on the competency and skill which are emphasized in the exercises.

\section{The Result}

After the writer analyzes in each exercise of listening exercise in Look Ahead 2 an English Course for Senior High School Grade Year XI, the table of content consisted of the information of page numbers of preface, what's so special about look ahead, Unit 1: Tell Me About It, Unit 2: Telling Stories (I), Unit 3: Figuring Out Conclusion, Unit 4: Telling Stories (II), Unit 5: Telling Funny Stories, and Unit 6: It Should Be Like This.

In this study, the writer analyzed the exercises which contained in the book of Look Ahead 2 an English Course for Senior High School Grade Year XI as a research tool. This research conducted to answer the research questions. The first research question "Are the listening exercises relevance to KTSP curriculum?".

In the first research question of relevancy with KTSP curriculum, the writer can conclude that listening exercise in Look Ahead 2 an English Course for Senior High School Year XI published by Erlangga is relevance with the KTSP curriculum because all of 16 listening exercise from 6 units (which is broken down into some subthemes of listening exercises: giving a report, listening a report, arranging paragraphs, retelling a story, making a fictional story, continuing a story, listening a horror, grammar in action, identifying language features and text structure, gathering information to support one's opinion, listening an analytical exposition, retelling funny story, telling funny experience, continuing a story, listening a spoof, making arguments, listening a thesis and a recommendation, listening a hortatory exposition) is demanded in listening based KTSP curriculum of Senior High School Grade Year XI, suitable of competency standard (SK) 2 . Understanding the meaning on short functional and simple monolog text with narrative, descriptive, and news item form in daily life contact and basic competency (KD) 2.1. Understanding the meaning on oral short functional of formal text and non formal accurately, fluently in daily life contact. 2.2. Understanding the meaning on monolog text who using a variety of oral language accurately, fluently and in daily life contact of item form: report, narrative, and analytical exposition.

The second research question is, "How the listening exercises in the text book look ahead 2 present items questions?". The writer conclude that from16 listening exercises there are twelve (12) listening exercises which is included in discrete test, that is exercise of task $\mathrm{C}$ (enjoy this) page 36-37, exercise of task $\mathrm{C}$ (second challenge) page 49, exercise of task $G$ (sixth challenge) page 53, exercise of task B (active listening) page 77 , exercise of task $G$ (sixth challenge) page 86, exercise of task B (active listening) page 119, exercise of task $\mathrm{C}$ (enjoy this) page 120-121, exercise of task B (active listening) page 157, exercise of task $\mathrm{C}$ (active listening) page 160, exercise of task B (first challenge) page 161, exercise of task B (active listening) page 181, exercise of task C (second challenge) page 186, 1 listening exercises which is included in communicative test, that is exercise of task A (think about it) page 48, and 3 listening exercises which is included in combination between both, that is exercise of task D (third) page 50, exercise of task $\mathrm{C}$ (second challenge) page 128 and exercise of task $\mathrm{C}$ (enjoy this) page 184. From this result, the listening exercise in Look Ahead 2, an English Course for Senior High School Grade Year XI published by Erlangga, show that the higest number of test is discrete test, so it is proper enough in improving of student's ability in listening through kind of this test. Since discrete test is a kind of point test which is more emphasized in accuracy.

\section{BIBLIOGRAPHY}

Alan Cunningsworth, 1984. Evaluating and Selecting ELF Teaching Materials, London: Heinemann Educational Press.

Azar. 2008. Definition Exercise, retrieved http://www.brainyquote. com/words/ex/ exercise162589.html. 28 November 2009

Brown, D. 2001. Teaching by Principles. An Interactive Approach to Language Pedagogy (Second Edition). New York: Longman.

Brown, G. 1990. Listening to spoken English (Second Edition). New York: Longman.

Byrne, D. 1976. Teaching Oral English. Longman Hand Books for English Teacher.England: Longman Group Publishing. 
Departemen pendidikan nasional RI, 2006, Kurikulum Sekolah Menengah. Kejuruan 2006. Jakarta, Depdiknas.

H. Douglas Brown, et. al. 1983. Audio Visual Instruction: Technology, Media and Method, (Australia: Mcquire University,).

Hornby, A S 1995. Advance Learners Dictionary, Oxford: Oxford University Press.

Jack C. Richards, 1998. Beyond Training, (Cambridge: Cambridge University Press,).

Jack C. Richards, 2002, Curriculum Development in Language Teaching, (Cambridge: Cambridge University Press.

Khaerudin, M.A DKK, Kurikulum Tingkat Satuan Pendidikan,( Jogjakarta, MDC\&Pilar Media, 2007).

Martin Parrot, Tasks for Language teacher (Cambridge: Cambridge University Press, 1993).

Neville Grant, Making The Most of Your Textbook, (New York: Longman, 1989).
Ninuk Dwi Wuriyani. 2008. Standar Isi dan Standar kompetensi Lulusan. (http://guruw.wordpress.com.pengemban gan-diri-dalam-ktsp/

$\neg$ Menu Download Kurikulum di Sekolah Maya Kota Banjar, 24 January 2012.

Omar Hamalik, 2007. Dasar- Dasar Pengembangan Kurikulum,( Bandung: Remaja Rosdakarya.

Peterson. S and Peterson. F 2002. The effects of post-task activities on the accuracy of language during task performance. (King's College, London).

Richards, J. 1983. Listening comprehension: Approach, design, procedure. TESOL Quarterly, 17(2), 219-240.

Rivers, W.M. 1981. Teaching foreign language skills (2nd ed.). Chicago: University of Chicago Press.

Rost, M. 1988. Listening in Language Learning. Great Britain: Prentice Hal International (UK) Ltd. 